\title{
Effect of Initial Low 0xygen Concentration on Respiration and Quality of Fresh-cut Cabbages
}

\author{
Hu, Wenzhong \\ Laboratory of Postharvest Science, Division of Bioproduction System Science, Department of \\ Bioproduciton Environmental Sciences, Faculty of Agriculture, Kyushu University
}

Tanaka, Shun-ichiro

Laboratory of Postharvest Science, Division of Bioproduction System Science, Department of Bioproduciton Environmental Sciences, Faculty of Agriculture, Kyushu University | Laboratory of Postharvest Science, Division of Bioproduction System Science, Department of Bioproduciton Environmental Sciences, Faculty of Agriculture, Kyushu University

Uchino, Toshitaka

Laboratory of Postharvest Science, Division of Bioproduction System Science, Department of Bioproduciton Environmental Sciences, Faculty of Agriculture, Kyushu University

\section{Kawasaki, Toship}

Laboratory of Postharvest Science, Division of Bioproduction System Science, Department of Bioproduciton Environmental Sciences, Draduate School of Bioresource and Bioenvironmental Sciences, Kyushu University

他

https://doi.org/10.5109/4543

出版情報：九州大学大学院農学研究院紀要. 48 (1/2)，pp. 195-207，2003-10-01. Faculty of Agriculture, Kyushu University

バージョン :

権利関係: 


\title{
Effect of Initial Low Oxygen Concentration on Respiration and Quality of Fresh-cut Cabbages
}

\author{
Wenzhong HU', Shun-ichiro TANAKA, Toshitaka UCHINO, \\ Takeshi NAKAMURA*, Toshio KAWAWAKI**, \\ Daisuke HAMANAKA** and Yoshiaki HORI
}

\author{
Laboratory of Postharvest Science, Division of Bioproduction System Science, Department of \\ Bioproduction Environmental Sciences, Faculty of Agriculture, \\ Kyushu University, Fukuoka 812-8581, Japan \\ (Received June 25, 2003 and accepted July 15, 2003)
}

\begin{abstract}
The effects of perforated film package (PFP) on the gas concentrations and respiration rates of fresh-cut cabbage with initial $\mathrm{O}_{2} 5,8,10$ and $21 \%$ were studied at 5 and $20^{\circ} \mathrm{C}$. The microbial growth, appearance, flavor and ascorbic acid content were also determined. The respiration rates of fresh-cut cabbages were suppressed under initial low $\mathrm{O}_{2}$ during storage of 4 days, especially in 5 and $8 \% \mathrm{O}_{2}$ concentrations. The anaerobic respiration did not occur under low $\mathrm{O}_{2}$ levels. It was also found that fresh-cut cabbages had better color retention and quality, reduced respiration rate and microbial population in PFP. Although there was the difference of quality attributes between PFP and MAP, but no significant difference was found.

The effect of initial low $\mathrm{O}_{2} 5 \%$ was the most important among different levels of initial low $\mathrm{O}_{2}$ according to the oxidation of ascorbic acid (AA) and browning of fresh-cut cabbage. Microbial analysis also showed that total count on the surface of fresh-cut cabbage was lowest among initial low $\mathrm{O}_{2}$ treatments. Total ascorbic acid (TAA) decreased by AA oxidation after cutting. Loss in TAA was much lower in PFP than that in MAP. Moreover, The results of sensory evaluation showed that there were no differences in all treatments at $5{ }^{\circ} \mathrm{C}$ throughout storage. At $20^{\circ} \mathrm{C}$, flavor reached 2-grade in all treatments and become 3-grade by 4 days in $21 \%$ MAP. The appearances were reached 2 -grades after 3 days in $10 \% \mathrm{PFP}$ and $21 \% \mathrm{MAP}$. These suggest that better quality of fresh-cut cabbage could be obtained from the combination of PFP with initial $\mathrm{O}_{2} 5-8 \%$ level and $5^{\circ} \mathrm{C}$.
\end{abstract}

\section{INTRODUCTION}

Fresh-cut horticultural products are prepared and handled to maintain their fresh nature while providing convenience to the user. The most food processing techniques stabilize the products and lengthen their storage and shelf life. While fresh-cut vegetables which increase in cut-damaged surface and availability of cell nutrients provide conditions that increase the number and type of microbes that develop and lead to greater opportunity for contamination by pathogenic organisms (Magnuson, et al., 1990; Marchetti, et al., 1992).

Microbial deterioration of fresh-cut vegetables can be controlled by several methods

* Q'SAI CO., LTD. Fukuoka, 810-8606 Japan

** Laboratory of Postharvest Science, Division of Bioproduction System Science, Department of Bioproduction Environmental Sciences, Graduate School of Bioresource and Bioenvironmental Sciences, Kyushu University

+ Corresponding author (E-mail:huxu@agr.kyushu-u.ac.jp) 
(Koseki, et al., 2001; Guerzoni, et al., 1996). Low temperature and packaging technology are vitally important ways to inhibit the proliferation of microorganisms. In particular, the use of permeable polymeric films could retard microbial growth by affecting the concentration of gases, but also maintain higher relative humidity to avoid water loss within the package (Watada, et al., 1996). Modified atmosphere packaging (MAP) has been considered to be effective method to extend the shelf life of fresh-cut fruits and vegetables (Kader, et al., 1986). The low $\mathrm{O}_{2}$ and high $\mathrm{CO}_{2}$ levels that are modified through the product's respiration and permeable film slow down respiration and have an effect of inhibited microbial growth in MAP (Zagory and Kader, 1989; Kader, et al., 1989; Lopez-Briones, et al., 1993). However, over tolerance limit to low $\mathrm{O}_{2}$ and high $\mathrm{CO}_{2}$, it resulted in shift from aerobic to anaerobic respiration and off-flavor and tissue breakdown. The improperly modified atmospheric conditions may adversely affect product quality. Therefore, the selection of suitable packaging materials is critical to obtain the desirable environment for extending the shelf life of fresh-cut vegetables. The optimum storage temperature and gas concentration need to be maintained during whole chain from harvest processing to consumption.

Fresh-cut processing increases the rate of metabolic processes that cause deterioration of fresh products. The physical damage or wounding caused by preparation increase respiration and ethylene production in short time, and associated increases in the rate of other biochemical reactions responsible for changes in color, flavor, texture and nutritional quality (Watada, et al., 1999). The reduction of wound-reduced metabolic activity is critical to control these changes. The respiration rate of fresh-cut product is an excellent indicator of metabolic activity of the fresh-cuts to guide the potential storage life. In previous paper, respiration rates of fresh-cut cabbage were investigated in MAP with OPP film, but anaerobic respiration and off-flavor occurred during storage due to beyond the low oxygen limit in MAP with lower permeability of OPP film ( $\mathrm{Hu}$, et al., 2003). The objectives of this study were to investigate the gas concentrations and the respiration rate of fresh-cut cabbage at initial low $\mathrm{O}_{2}$ concentrations in PFP and MAP. The effect of initial low $\mathrm{O}_{2}$ on microbial growth and quality was also determined.

\section{MATERIALS AND METHODS}

\section{Plant material}

Cabbages (cv: Akitoku) were obtained from the local supermarket in Fukuoka city, Japan. Samples were transported to the laboratory without refrigeration and immediately processed. Cabbages were selected for uniform size and appearance. Outer and damaged leaves were removed.

\section{Cabbage slice preparation}

The cabbages were washed with tap water before cutting. Knife and cutting board were washed and treated with $75 \%$ ethanol prior to use. The cabbage was cut into $1.5 \mathrm{~mm}$ width and $5 \mathrm{~mm}$ length by hand with a sharp stainless steel knife. The slices were washed for $6 \mathrm{~min}$ with distilled water and then washed with $2{ }^{\circ} \mathrm{C}$ distilled water for $4 \mathrm{~min}$. The slices were centrifuged for $3 \mathrm{~min}$ at 1,720 (rpm) to remove the water on the cabbage surface by washing machine. And then slices were selected at random and samples of 
$100 \pm 1 \mathrm{~g}$ were placed in the package $(10 \times 20 \mathrm{~cm})$ and heat sealed. A silicone cap was applied on each package to permit analysis of package headspace with a syringe. The initial low $\mathrm{O}_{2}$ concentrations were regulated with $99.99 \% \mathrm{~N}_{2}$ gas and the void volume in the package was regulated into $300 \mathrm{ml}$ by $200 \mathrm{ml}$ syringe. All processing operations were conducted at $5-8^{\circ} \mathrm{C}$. The film used for cabbage slices package was oriented polypropylene (OPP) film with thickness $30 \mu \mathrm{m}$ (Sumitomo Bakelite Co., Ltd, Tokyo Japan). Micro-perforation $(0.1 \mathrm{~mm}$ in diameter, one hole on each package) was made with needle with $0.1 \mathrm{~mm}$ tip. The perforated film packages (PFP) and MAP were stored at 5 and $20^{\circ} \mathrm{C}$ for 4 days, respectively. Samples were removed on days $0,1,2,3$ and 4 for analyses of gas composition, quality and microbial population.

\section{Gas analysis}

Gas sample was withdrawn by gas-tight $1.0 \mathrm{ml}$ syringe from the inside the package. The gas concentrations were measured by injecting $1.0 \mathrm{ml}$ gas sample into gas chromatography (GL Sciences GC-390, Tokyo Japan) equipped with thermal conductivity detector (TCD) and D2000 integrator (Hitachi, Ltd. Tokyo Japan). Helium was used as carrier gas and the flow rate was $30 \mathrm{ml} \cdot \mathrm{min}^{-1}$. The injector and column temperatures were 80 and $50^{\circ} \mathrm{C}$, respectively. The column was WG100 with molecular sieve $5 \mathrm{~A}$ and Porapak Q 80/100 mesh.

\section{Mathematical model for respiration}

The equations of basic volume balance can be used to determine the respiration rate of fresh-cut cabbage in the packages (Akimoto et al., 1997). The changes in the free volume of gas within package at the short time were calculated (Hu et al., 2003).

\section{Ascorbic acid}

Ascorbic acid content was measured by high performance liquid chromatography (HPLC) equipped with Shim-pack SCR-101N column $(7.9 \mathrm{~mm} \phi \times 30 \mathrm{~cm})$ (Shimadzu Corp., Tokyo Japan). The column is packed with a cation exchanger resin which is sulfonated polystylene-divinylbenzene copolymer. The mobile phase was mixed solution of $10 \mathrm{mM}$ oxalic acid dihydrate, $15 \mathrm{mM} \mathrm{N} \mathrm{N}_{\mathrm{a}} \mathrm{OH}$ and $1 \mathrm{mM}$ EDTA at a flow rate of $1.0 \mathrm{ml} \mathrm{min}^{-1}$. Temperature is $40^{\circ} \mathrm{C}$ and detector is RI. Cabbage sample was extracted from excised slices of $5 \mathrm{~g}$ cabbage with 5 times the volume of $5 \%$ metaphosphoric acid in a mortar with pestle. The homogenate was filtered through filter paper and centrifuged at 3,000 (rpm) for $15 \mathrm{~min}$. The supernatant was taken as sample to measure the ascorbic acid content in cabbage.

\section{Microbial analysis}

The Microbial populations were determined by incubating extracts of fresh-cut cabbage on culture medium of potato dextrose agar (PDA) spread with $0.1 \mathrm{ml}$ extraction during $48 \mathrm{~h}$ at $30^{\circ} \mathrm{C}$ during storage (Babic and Watada, 1996). Colonies were counted and

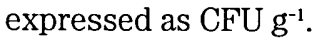

\section{Sensory evaluations}

Appearance and flavor were evaluated by five people during storage. Evaluation was 
carried out in two items of appearance and flavor. They were both scored on 4-point scale: excellent 1 ; very good 2 ; fair 3 ; poor 4 .

\section{Browning measurement}

A $40 \mathrm{~g}$ of sample was weighed, cut and homogenized with $80 \%$ ethanol by homogenizer to remove chlorophyll. And then sample was filtered through filter paper. The residue and filter paper was dried at $60^{\circ} \mathrm{C}$ in the constant temperature drier for $12 \mathrm{~h}$. The dried residue was placed in a mortar with pestle to make micro-powder. The powder was put on the slide glass $2 \mathrm{~mm}$ in thickness and covered with the cover glass. The color of the powder was determined by using a chromameter (model CR 200; Minolta Corp., Japan). A tristimulus colorimeter with an $11 \mathrm{~mm}$ aperture and diffuse illumination ( $\mathrm{C}$ light source) was calibrated with a white standard calibration plate $(\mathrm{Y}=92.9, \mathrm{x}=0.3136, \mathrm{y}=0.3200)$. Expression of color was characterized as Hunter color indexes $L^{*}, a^{*}$ and $b^{*}$; where $L^{*}$ indicates the lightness, $a^{*}$ means the color axis from green to red, $b^{*}$ the blue-yellow color axis. The changes in the browning of fresh-cut cabbage were shown in following equation (Yano, et al., 1986).

$$
\Delta E(L a b)=\sqrt{\left(L-L_{0}\right)^{2}+\left(a-a_{0}\right)^{2}+\left(b-b_{0}\right)^{2}}
$$

Where $\Delta E(L a b)$ : browning degree; $L_{0}, a_{0}, b_{0}$ : value after cutting cabbage; $L, a, b$ : changing value during storage.

\section{RESULTS AND DISCUSSION}

\section{Changes in gas concentration in packages}

Changes in the $\mathrm{O}_{2}$ and $\mathrm{CO}_{2}$ contents in packages at $5{ }^{\circ} \mathrm{C}$ was shown in Fig. 1 The $\mathrm{O}_{2}$ level in $5 \%$ PFP gradually increased to $7.2 \%$, while $\mathrm{CO}_{2}$ level increased to $4.9 \%$ by $72 \mathrm{~h}$ (Fig. $1 \mathrm{~A}$ ). In $8 \% \mathrm{PFP}$, the $\mathrm{O}_{2}$ level was stable in about $8 \%$ and $\mathrm{CO}_{2}$ levels was reached $5 \%$ (Fig. 1B). For 10\% PFP (Fig. 1C), gas composition was increased to $12.3 \%$ for $\mathrm{O}_{2}$ and $4.9 \%$ for $\mathrm{CO}_{2}$. But $\mathrm{O}_{2}$ was decreased from $21 \%$ to $12.5 \%$ and $\mathrm{CO}_{2}$ increased from 0.03 to $5.5 \%$ in $21 \%$ MAP. Among all the samples, highest $\mathrm{CO}_{2}$ content was $5.2 \%$ and lowest $\mathrm{O}_{2}$ content was $7.1 \%$, which were within the safe levels from toxicity or anoxia. It was indicated that the perforation on the film played an important role in regulating gas levels based on the relative stable changes in gas concentrations in PFP. For the control, $\mathrm{O}_{2}$ level decreased from $21 \%$ to $12.5 \%$, while $\mathrm{CO}_{2}$ increased from $0.03 \%$ to $5.5 \%$ by $72 \mathrm{~h}$ (Fig. 1D). The similar conditions of $\mathrm{CO}_{2}$ and $\mathrm{O}_{2}$ atmospheric were obtained at $5^{\circ} \mathrm{C}$ by $72 \mathrm{~h}$.

Changes in the $\mathrm{O}_{2}$ and $\mathrm{CO}_{2}$ contents in packages at $20^{\circ} \mathrm{C}$ was shown in Fig. 2. The remarkable changes in gas compositions were occurred throughout storage. $\mathrm{O}_{2}$ level in $5 \%$ PFP decreased to $2.2 \%$ within $8 \mathrm{~h}$, then increased more rapidly to $4.2 \%$ by $72 \mathrm{~h}$ (Fig. $2 \mathrm{~A}$ ). While the $\mathrm{CO}_{2}$ level increased to $12 \%$ quickly, and then fluctuated about $13 \%$ by hour 72 . In $8 \% \mathrm{PFP}$, the changes in $\mathrm{O}_{2}$ and $\mathrm{CO}_{2}$ levels were similar to that in $5 \% \mathrm{PFP}$ (Fig. 2B). In $10 \% \mathrm{PFP}, \mathrm{O}_{2}$ decreased to $2.2 \%$ by $44 \mathrm{~h}$, and then fluctuated in about this level. $\mathrm{CO}_{2}$ increased to $15.2 \%$ by $44 \mathrm{~h}$, and then did not change much by $72 \mathrm{~h}$. The $\mathrm{O}_{2}$ decreased from $21 \%$ to $1.4 \%$ much quickly by $22 \mathrm{~h}$, and then increased slightly. $\mathrm{CO}_{2}$ increased to $14 \%$ by $22 \mathrm{~h}$, and then fluctuated about $14.5 \%$ (Fig. $2 \mathrm{C}$ ). Although $\mathrm{O}_{2}$ level decreased to lower than $2.2 \%$, and then increased gradually in all the initial low $\mathrm{O}_{2}$ treatments. It was considered that respiration was suppressed by lower $\mathrm{O}_{2}$ level at initial period, and $\mathrm{O}_{2}$ level 

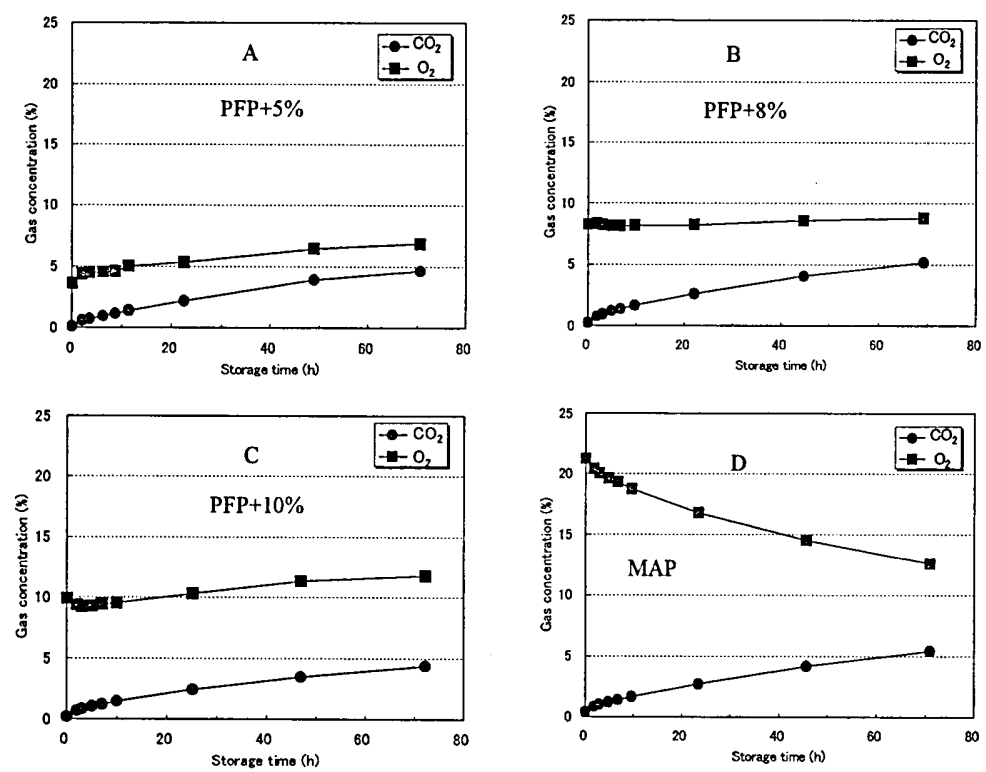

Fig. 1. Changes in gas concentrations in perforated film packages (PFP) with different initial oxygen concentrations and MAP at $5^{\circ} \mathrm{C}$.
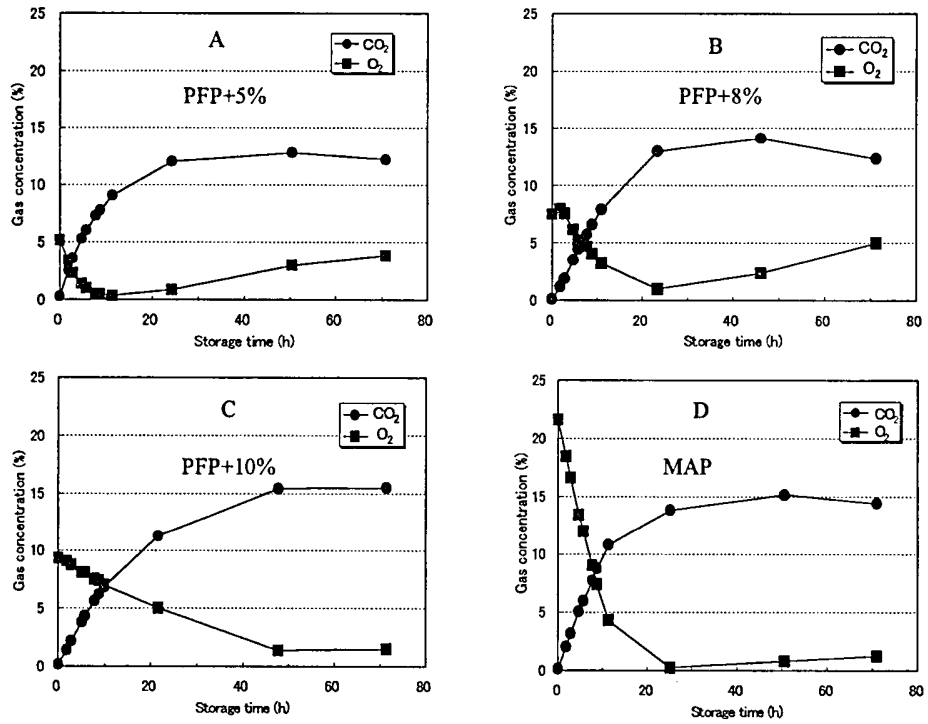

Fig. 2. Changes in gas concentrations in perforated film packages (PFP) with different initial oxygen concentrations and MAP at $20^{\circ} \mathrm{C}$. 
was regulated to increase by the hole on the film. For the control, $\mathrm{O}_{2}$ level decreased at highest speed at initial storage period among all treatments, and then increased slightly due to without getting enough supply through the film (Fig. 2D). $\mathrm{CO}_{2}$ levels showed similar changing trend in all the samples.

\section{Respiration rate}

It has been reported that perforated film package are suitable for high respiration commodities such as strawberry (Chambroy, et al., 1993), mushroom (Lopez-Briones, et $a l ., 1993$ ) and fresh-cut products (Emond, et al., 1991) because of its higher permeability for $\mathrm{O}_{2}$ and $\mathrm{CO}_{2}$. In the previous paper, anaerobic respiration was occurred in MAP with OPP film without perforation due to low permeability of film and higher respiration rate of fresh-cut cabbage.

The changes in the respiration rate of fresh-cut cabbage were shown in Fig. 3. The respiration rate decreased slightly at the conditions of increasing $\mathrm{O}_{2}$ and decreasing $\mathrm{CO}_{2}$ concentrations at $5^{\circ} \mathrm{C}$ by $72 \mathrm{~h}$ (Fig. $3 \mathrm{~A}$ ). The respiration rates were decreased at initial 4 $\mathrm{h}$, and then fluctuated in $5-8 \mathrm{CO}_{2} \mathrm{ml} \cdot \mathrm{kg}^{-1} \cdot \mathrm{h}^{-1}$ by the end of experiment. The respiration
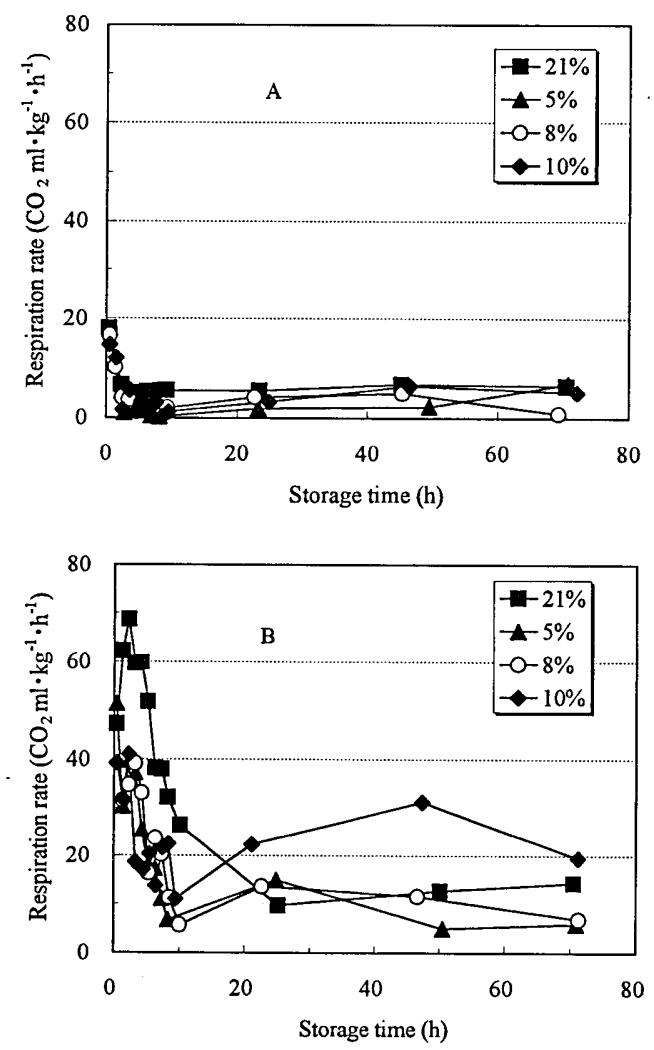

Fig. 3. Respiration rate of fresh-cut cabbage in perforated film packages and MAP at different temperatures $\left(\mathrm{A}: 5^{\circ} \mathrm{C}, \mathrm{B}: 20^{\circ} \mathrm{C}\right)$. 
rates remained stable for the duration of the experiment. There was no significant difference among the three levels of initial low $\mathrm{O}_{2}$. But for control, respiration rate was relative higher than that at initial low $\mathrm{O}_{2}$ levels.

At $20^{\circ} \mathrm{C}$, respiration rate was increased at initial $3 \mathrm{~h}$, and then decreased quickly from 64.6 to $10.3 \mathrm{CO}_{2} \mathrm{ml} \cdot \mathrm{kg}^{-1} \cdot \mathrm{h}^{-1}$ by $22 \mathrm{~h}$ and slightly increased to $15 \mathrm{CO}_{2} \mathrm{ml} \cdot \mathrm{kg}^{-1} \cdot \mathrm{h}^{-1}$ due to anaerobic respiration confirmed by higher respiratory quotient values (4.1) in $21 \%$ MAP (Fig. 3B). While in PEP, respiration rates were suppressed markedly with quickly increasing $\mathrm{CO}_{2}$ and decreasing $\mathrm{O}_{2}$ levels at initial $10 \mathrm{~h}$, and then fluctuated $5-10 \mathrm{CO}_{2} \mathrm{ml}$ $\mathrm{kg}^{-1} \cdot \mathrm{h}^{-1}$. It was indicated that gas composition in PEP was modified through the low product's respiration and the hole on the package (Fig. 2). It has been reported that the modified atmospheres that best maintain the quality and storage life of fresh-cut products have an $\mathrm{O}_{2}$ range of $2-8 \%$ and $\mathrm{CO}_{2} 5-15 \%$. In this experiment, active modified atmospheric conditions of low $\mathrm{O}_{2}$ level were established quickly by gas flushing to increase the shelf life and quality of fresh-cut cabbage. The permeability of film was improved by perforated on the package to avoid occurrence of much lower $\mathrm{O}_{2}$ atmosphere. Therefore, atmospheric conditions were modified through the product's respiration and permeability of perforated film to maintain aerobic respiration in PEP during the storage (Renault, et al., 1994).

The storage life of horticultural products has well been related to the respiration rate of products, the suppression of respiratory metabolism will extend the shelf life of stored fresh product (Lopez-Briones, et al., 1992; Kader, 1986). But $\mathrm{O}_{2}$ and $\mathrm{CO}_{2}$ levels beyond its tolerance limits can induce anaerobic respiration and $\mathrm{CO}_{2}$ damage to result in browning and development of off-flavors. It was suggested that better keeping quality for fresh-cut cabbages could be obtained from low $\mathrm{O}_{2}$ storage atmosphere above $2.2 \%$. For the effect of initial low $\mathrm{O}_{2}$, there were no significant differences in changes in gas concentration and respiration rate between $5 \% \mathrm{PEP}$ and $8 \% \mathrm{PEP}$ at 5 and $20^{\circ} \mathrm{C}$ during storage.

MAP can be beneficial in maintaining quality of the fresh-cut product (Gorny, 1997). The suitable gas mixture for MAP has been based on that recommended for the whole commodity (Saltveit, 1997). Fresh-cut products probably can tolerate more extreme levels of $\mathrm{O}_{2}$ and $\mathrm{CO}_{2}$, because they do not have as much cuticle or skin to restrict gas diffusion, and the distance of gas diffusion from center to outside of fresh-cut product is much less than that for the whole commodity (King, et al., 1989). It was also reported that an additional benefit of MAP may be attained by actively flushing the package with the desired gas rather than allowing the MAP to develop naturally since the marketing period of fresh-cut product is relatively short (Bai, et al., 2001). In the previous study, fresh-cut cabbage has much higher respiratory activity to consume $\mathrm{O}_{2}$ and produce $\mathrm{CO}_{2}$ quickly. Anaerobic respirations were occurred after 3 days of storage at $5^{\circ} \mathrm{C}$ and after 1 day of storage at $20^{\circ} \mathrm{C}$, and lead to browning and development of off-flavors of fresh-cut cabbage (Hu, et al., 2003). Although benefits may occur with modified atmosphere, the extinction point of the fresh-cut products must be recognized to avoid anaerobic respiration (Ko, et al., 1996). In this experiment, relative optimum atmospheric conditions were maintained by regulating initial low $\mathrm{O}_{2}$ and perforation on the package.

Fresh-cuts generally are much more perishable than intact products because they have been subjected to severe physical stress, such as peeling, cutting, slicing, shredding, trimming and removal of protective cells. Consequently, fresh-cuts probably should be 
held at a lower temperature than that recommended for intact commodities. Temperature of $0^{\circ} \mathrm{C}$ is in most case preferable. However, this is in most cases economically not achievable. Temperature between 5 and $10^{\circ} \mathrm{C}$ is more commonly found in practice. In this experiment, respiration rate were maintained relative lower levels at $5^{\circ} \mathrm{C}$ than that at $20^{\circ} \mathrm{C}$. The temperature effects on the tissue metabolism and biochemical reactions significantly, it is also of major important to maintain low temperature to prevent microbial growth. It suggests that it is important for handling and storing fresh-cut cabbage at lower temperature or near $0^{\circ} \mathrm{C}$ (Gorny, 1997), if the product is not sensitive to chilling injury.

\section{Ascorbic acid}

Fig. 4 shows loss in total ascorbic acid (TAA) contents at different initial $\mathrm{O}_{2}$ concentrations for fresh-cut cabbage at the end of storage. In 5\% and 8\% PFP, losses in TAA were similar, that is 9.2 and $9.3 \%$, respectively. It was indicated that initial $\mathrm{O}_{2} 5 \%$ and $8 \%$ have same effects on suppressing ascorbic acid (AA) oxidation at $5^{\circ} \mathrm{C}$. While in $10 \% \mathrm{PFP}$ and $21 \%$ MAP, the rates of loss in TAA were 11.2 and $22.1 \%$, respectively. It demonstrated that initial low $\mathrm{O}_{2}$ not only suppressed the respiration, but also significantly inhibited activity of ascorbate oxidase to avoid the AA oxidation.

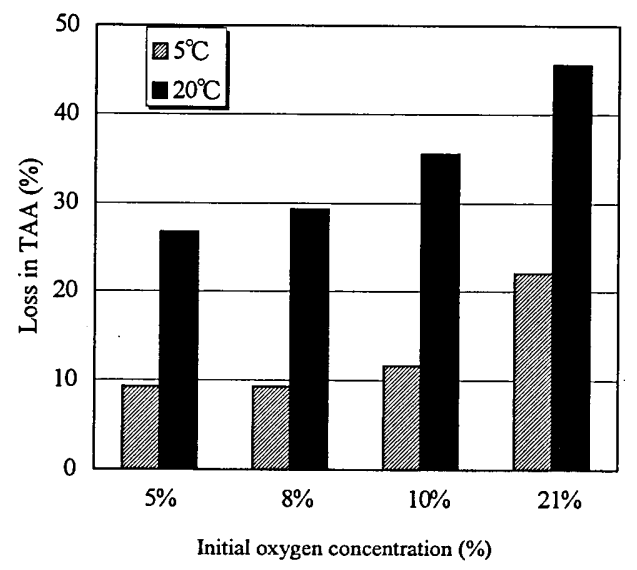

Fig. 4. Loss in total ascorbic acid in perforated film packages and MAP at different temperatures.

It could be also assumed that the role of $\mathrm{AA}$ as $\mathrm{s}$ reducing power in respect to de nova synthesis of polyphenols is possible. Ascorbic acid plays an important role in the defence mechanism against free radicals that induce peroxidation (Barth, et al., 1991). AA can be easily oxidised to dehydroascorbic acid, the latter in turn can either be reduced.

\section{Browning}

The changes in browning ( $\Delta E(L a b))$ of fresh-cut cabbage were shown in Fig. 5. The 

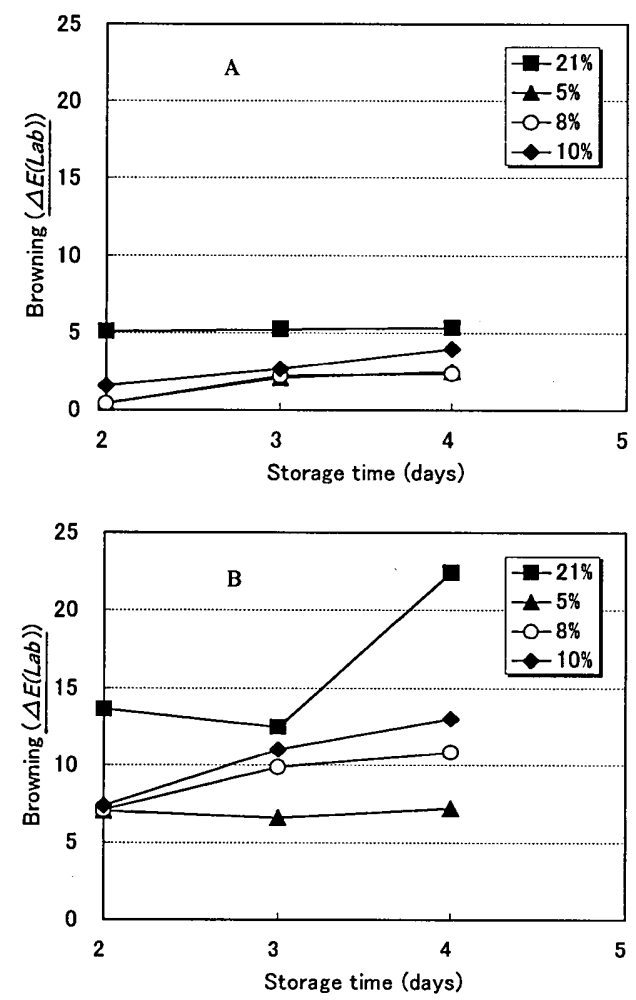

Fig. 5. Effects of initial low oxygen concentration on the browning of fresh-cut cabbage at different temperatures $\left(\mathrm{A}: 5^{\circ} \mathrm{C}, \mathrm{B}: 20^{\circ} \mathrm{C}\right)$.

browning degree increased to 5.2 slightly with relative higher initial value in $21 \%$ MAP at $5{ }^{\circ} \mathrm{C}$ (Fig. 5A). While in PFP, the browning increased slowly throughout storage. Among the initial low $\mathrm{O}_{2}$ treatments, $10 \%$ PFP had highest value (4.2), but they were lower (2.5-4.2) than that in 21\% MAP (5.2). At $20^{\circ} \mathrm{C}$ (Fig. 5B), the browning degree decreased slightly by 3 days and then increased to 22.5 quickly in 21\% MAP. While in PFP, the browning increased slowly throughout storage. Among the initial low $\mathrm{O}_{2}$ treatments, $10 \%$ PFP had highest value (13.2), but they were lower (7.1-13.2) than that in $21 \%$ MAP (13.2). It indicated that browning degree was suppressed markedly in initial low $\mathrm{O}_{2}$ levels. Moreover, the browning was much lower at $5^{\circ} \mathrm{C}$ than that at $20^{\circ} \mathrm{C}$. Low temperature is important essential for storing and maintaining quality of fresh-cut vegetables.

\section{Sensory evaluation}

Sensory evaluation of fresh-cut cabbage was shown in Table 1. Visual appearances and flavor were not changed much during storage of 4 days in all treatments at $5^{\circ} \mathrm{C}$. At $20^{\circ} \mathrm{C}$, off-flavor was occurred after 1 day and then not change much in all treatments. But for the control, flavor was reached 3 -grade by 4 days. The appearances were reached 
Table 1. Sensory evaluation of fresh-cut cabbage at different storage conditions

\begin{tabular}{|c|c|c|c|c|c|c|}
\hline \multirow{2}{*}{ Items } & \multirow{2}{*}{$\begin{array}{c}\text { Temperature } \\
\left({ }^{\circ} \mathrm{C}\right)\end{array}$} & \multirow{2}{*}{$\begin{array}{c}\text { Initial } \mathrm{O}_{2} \text { concentration } \\
(\%)\end{array}$} & \multicolumn{4}{|c|}{ Storage time (day) } \\
\hline & & & 1 & 2 & 3 & 4 \\
\hline \multirow{8}{*}{ Flavor } & \multirow{4}{*}{$5^{\circ} \mathrm{C}$} & 5 & 1 & 1 & 1 & 1 \\
\hline & & 8 & 1 & 1 & 1 & 1 \\
\hline & & 10 & 1 & 1 & 1 & 1 \\
\hline & & 21 & 1 & 1 & 1 & 1 \\
\hline & \multirow{4}{*}{$20^{\circ} \mathrm{C}$} & 5 & 1 & 2 & 2 & 2 \\
\hline & & 8 & 1 & 2 & 2 & 2 \\
\hline & & 10 & 1 & 2 & 2 & 2 \\
\hline & & 21 & 1 & 2 & 2 & 3 \\
\hline \multirow{8}{*}{ Appearance } & \multirow{4}{*}{$5^{\circ} \mathrm{C}$} & 5 & 1 & 1 & 1 & 1 \\
\hline & & 8 & 1 & 1 & 1 & 1 \\
\hline & & 10 & 1 & 1 & 1 & 1 \\
\hline & & 21 & 1 & 1 & 1 & 1 \\
\hline & \multirow{4}{*}{$20^{\circ} \mathrm{C}$} & 5 & 1 & 1 & 1 & 1 \\
\hline & & 8 & 1 & 1 & 1 & 1 \\
\hline & & 10 & 1 & 1 & 2 & 2 \\
\hline & & 21 & 1 & 1 & 2 & 2 \\
\hline
\end{tabular}

2-grades after 3 days. It was explained that the changes in appearance and flavor were due to relative higher activity of physiological metabolism of fresh-cut cabbage at $20^{\circ} \mathrm{C}$.

\section{Microbial analysis}

The effects of initial low $\mathrm{O}_{2}$ levels on the microbial counts on the surface of fresh-cut cabbage were shown in Fig. 6 . At $5^{\circ} \mathrm{C}$, bacterial counts increased from $4.6 \times 10^{5}$ to $1.1 \times$ $10^{6} \mathrm{CFU} \mathrm{g}^{-1}$ in $21 \%$ MAP by 2 days, and reached $2.4 \times 10^{6} \mathrm{CFU} \mathrm{g}^{-1}$ by 4 days. While bacterial counts increased from $4.6 \times 10^{5}$ to $8.4 \times 10^{5} \mathrm{CFU} \mathrm{g}^{-1}$ in $5 \% \mathrm{PFP}, 4.6 \times 10^{5}$ to $9.0 \times$ $10^{5} \mathrm{CFU} \mathrm{g}^{-1}$ in $8 \% \mathrm{PFP}$ by day 2 , respectively (Fig. $6 \mathrm{~A}$ ). After the end of 4 -day experiment, bacterial counts were about $1.8 \times 10^{6} \mathrm{CFU} \mathrm{g}^{-1}$ in both PFP. It was indicated that the effect of initial low $\mathrm{O}_{2}$ on the proliferation and growth of microorganisms was not obvious at $5{ }^{\circ} \mathrm{C}$ due to remarkable suppression of the microbial proliferation by low temperature. At $20^{\circ} \mathrm{C}$, bacterial counts increased from $4.6 \times 10^{5}$ to $1.4 \times 10^{7} \mathrm{CFU} \mathrm{g}^{-1}$ by 2 days and reached $2.5 \times 10^{7} \mathrm{CFU} \mathrm{g}^{-1}$ by 4 days in $21 \% \mathrm{MAP}$. While bacterial counts increased from $4.6 \times 10^{5}$ to $1.1 \times 10^{6} \mathrm{CFU} \mathrm{g}^{-1}$ in $5 \% \mathrm{PFP}$, and then was $3.1 \times 10^{6} \mathrm{CFU} \mathrm{g}^{-1}$ by 4 days. In $8 \% \mathrm{PFP}$, from initial value $4.6 \times 10^{5}$ to $5.5 \times 10^{6} \mathrm{CFU} \mathrm{g}^{-1}$ by 2 days, and then increased to $5.8 \times 10^{6} \mathrm{CFU} \mathrm{g}^{-1}$ by 4 days (Fig. $6 \mathrm{~B}$ ). Microbial analysis showed that the average total plate count on the surface of fresh-cut cabbage was increased during storage, especially at $20^{\circ} \mathrm{C}$. The storage temperature has significant effect on the increase in the total plate count. There was lower increasing rate of the total plate count at $5^{\circ} \mathrm{C}$ than that at $20^{\circ} \mathrm{C}$, and the total plate count was lower in PFP than that in MAP.

The microbial populations in PFP were significantly lower than that in MAP. Microbial populations increased most rapidly at the higher storage temperature (Fig. 6B). It was indicated that low levels of $\mathrm{O}_{2}$ in packages inhibited the growth of aerobic microor- 

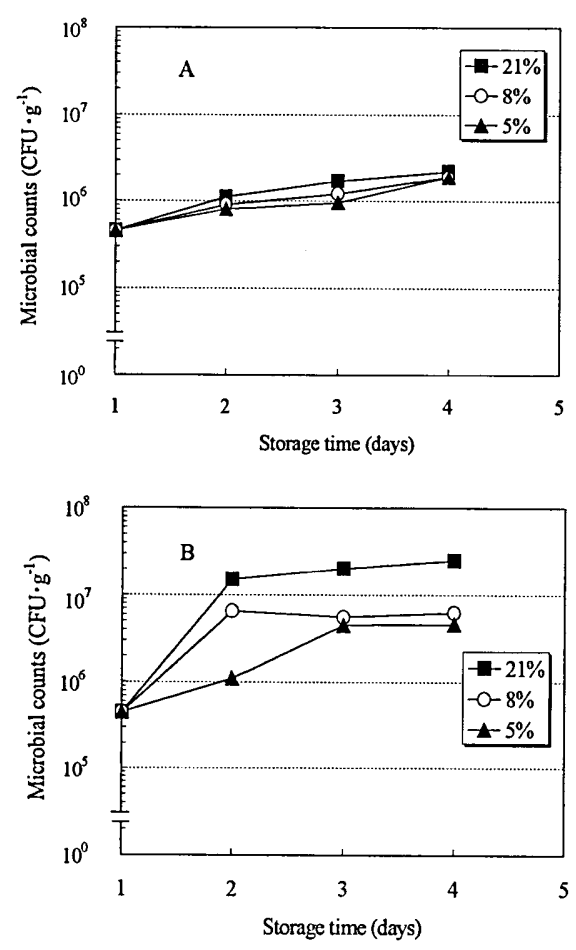

Fig. 6. Effect of initial low concentration on microbial counts on the surface of fresh-cut cabbage at different temperatures $\left(\mathrm{A}: 5^{\circ} \mathrm{C}, \mathrm{B}: 20^{\circ} \mathrm{C}\right.$ ).

ganisms. Although the degrees to which $\mathrm{CO}_{2}$ and $\mathrm{O}_{2}$ were modified in PFP and MAP in this study were not enough to inhibit microbial growth completely, the microbial populations were much lower in initial low $\mathrm{O}_{2}$ modifications than that in MAP. One possible explanation for our finding is that the initial low $\mathrm{O}_{2}$ modifications of PFP had an additive retarding effect on microbial growth, and showed the significant effect at higher temperature.

McGill et al. (1966) found that spinach leaves packages in $9.5 \% \mathrm{CO}_{2}$ and $3.3 \% \mathrm{O}_{2}$ had lower microbial counts than samples packaged in air. Similarly, Babic and Watada (1996) reported that low $\mathrm{O}_{2}$ combined with high $\mathrm{CO}_{2}$ reduced the number of microorganisms on fresh-cut spinach by 10 -fold or even 100 -fold compared with air at $5{ }^{\circ} \mathrm{C}$ due to probably decreased oxygen availability. In this experiment, initial low $\mathrm{O}_{2}$ (active MAP) could be used to control microbial development on fresh-cut cabbage at $5^{\circ} \mathrm{C}$. Bai et al. (2001) reported that the desired atmosphere was obtained by the active MAP system with low $\mathrm{O}_{2}$ level for retaining shelf life of fresh-cut cantaloupe. Qi et al. (1999) reported that lower microbial population and longer shelf life of honeydew cubes stored at $5^{\circ} \mathrm{C}$ rather than at $10^{\circ} \mathrm{C}$ in both air and controlled atmosphere. It indicated that low storage temperature, especially constant low temperature was important for the extending shelf life of 
fresh-cut vegetables.

\section{CONCLUSIONS}

The effects of perforated film package on the gas concentrations and respiration rates of fresh-cut cabbage with initial $\mathrm{O}_{2} 5,8,10$ and $21 \%$ were studied at 5 and $20^{\circ} \mathrm{C}$. The microbial growth and quality were also evaluated. The respiration rates of fresh-cut cabbages were suppressed under initial low $\mathrm{O}_{2}$ during storage of 4 days, especially in 5 and $8 \% \mathrm{O}_{2}$ concentrations. The anaerobic respiration did not occur under low $\mathrm{O}_{2}$ levels. It was also found that fresh-cut cabbages had better color retention and quality, reduced respiration rate and microbial population in PFP. Although there was the difference of quality attributes between PFP and MAP, but no significant difference was found.

The effects of initial low $\mathrm{O}_{2} 5 \%$ was the most remarkable among different levels of initial low $\mathrm{O}_{2}$ according to the oxidation of ascorbic acid (AA) and browning of fresh-cut cabbage. Microbial analysis also showed that total count on the surface of fresh-cut cabbage was lowest among initial low $\mathrm{O}_{2}$ treatments. Total ascorbic acid (TAA) decreased by AA oxidation after cutting. Loss in TAA was much lower in PFP than that in MAP. Moreover, The results of sensory evaluation showed that there were no differences at $5^{\circ} \mathrm{C}$ throughout storage. At $20^{\circ} \mathrm{C}$, flavor reached 2-grade in all treatments and become 3 -grade by 4 days in $21 \% \mathrm{MAP}$. The appearances were reached 2-grades after 3 days in $10 \% \mathrm{PFP}$ and $21 \% \mathrm{MAP}$. These suggest that better quality of fresh-cut cabbage could be obtained from the combination of PFP with initial $\mathrm{O}_{2} 5-8 \%$ level and $5^{\circ} \mathrm{C}$.

\section{REFERENCES}

Akimoto, K. and S. Maezawa 1997 A new method for estimating respiration rate of fruits and vegetables in modified atmosphere packaging. $J$. of the J. Soc. Agri. Machineary, 59(1): 109-116 (In Japanese)

Babic I. and A. E. Watada 1996 Microbial populations of fresh-cut spinach leaves affected by controlled atmospheres. Postharvest Biol. Technol., 9: 187-193

Bai, J. H., R. A. Saftner, A. E. Watada and Y. S. Lee 2001 Modified atmosphere maintains quality of fresh-cut cantaloupe (Cucumis melo L.). J. Food Sci., 66: 1207-1211

Barth, M. M., E. L. Kerbel, S. Broussard and S. J. Schmidz 1991 Modified atmosphere packaging protects market quality in broccoli spears under ambient temperature storage. J. Food Sci., 58: 1070-1072

Chambroy, Y., M. H. Guinebretiere, G. Jacquemin, M. Reich, L. Breuils and M. Souty 1993 Effects of carbon dioxide on shelf-life and postharvest decay of strawberry fruit. Sci. fes Aliments, 13: $409-423$

Edond, D. 1991 Mathematical modeling of gas exchange in modified atmosphere packaging. Transaction ASAE, 34: 239-245

Gorny, J. R., M. I. Gil and A. A. Kader 1998 Postharvest physiology and quality maintenance of fresh-cut pears. Acta Hort., 464: 231-236

Gorny, J. R. 1997 Summary of CA and MA requirements and recommendations for fresh-cut (minimally processed) fruits and vegetables. Proceedings of Seventh International Controlled Atmosphere Conference, Vol. 5. Postharvest Outreach Program, University of California, Davis, CA: 30-66

Guerzoni, M. E., A. Gianotti, M. R. Corbo and M. Sinigalia 1996 Shelf-life modeling for fresh-cut vegetables. Postharvest Biol. Technol., 9: 195-207

Hu, W., T. Uchino, T. Nakamura, N, Furuse, D, Hamanaka, H, Sorour, Y. Hori and S. Tanaka 2003 Repiration and quality of fresh-cut cabbages in modified atmosphere packaging, J. Fac. Agr. Kyushu Univ., 47: 149-158

Kader, A. A. 1986 Biochemical and physiological basis for effects of controlled and modified 
atmospheres on fruits and vegetables. Food Technol., 5: 99-104

Kader, A. A, D. Zagory and E. L. Kerbel 1989 Modified atmosphere packaging of fruits and vegetables. Critical reviews in food science and nutrition, 28: 1-29

King, A. D. and H. R. Bolin 1989 Physiological and microbiological storage stability of minimally processed fruits and vegetables. Food Technol., 2: 132-135

Ko, N. P., A. E. Watada, D. V. Schlimme and J. C. Bouwkamp 1996 Storage of spinach under low oxygen atmosphere above the extinction point. J. Food Sci., 61: 398-400+406

Koseki, S, K. Yoshida, S. Isobe and K. Itoh 2001 Decontamination of lettuce using acidic electrolyzed water. J. Food Prot., 64: 652-658

Lopez-Briones, G., P. Varoquaux, Y. Chambroy, J. Bouquant, G. Bureau and B. Pascat 1992 Storage of common mushroom under controlled atmospheres. Inter J Food Sci Technol., 27: 493-505

Lopez-Briones, G., P. Varoquaux, G. Bureau and B. Pascat 1993 Modified atmosphere packaging of common mushroom. Inter J Food Sci Technol., 28: 57-68

Magnuson, J. A., A. D. King and T. Torok 1990 Microflora of partially processed lettuce. Appl. Environ. Microbial., 56: 3851-3560

Marchetti, R., M. A Casadei and M. E. Guerzoni 1992 Microbial population dynamics in ready-to-use vegetable salads. Ital. J. Food Sci., 2: 97-108

Mcgill, JN., A. L. Nelson, and M. P. Steinberg 1966 Effects of modified storage atmosphere on ascorbic acid and other quality characteristics of spinach. J. Food Sci., 31: 510-516

Qi, L., T. Wu and A. E. Watada 1999 Quality changes of fresh-cut honeydew melons during controlled atmosphere storage. J. Food Qual., 22: 513-521

Renault, P., M. Souty and Y. Chambroy 1994 Gas exchange in modified atmosphere packaging. 1: A new theoretical approach for micro-perforated packs. Inter J Food Sci Technol., 29: 365-378

Sltveit, T. J. 1997 Summary of CA and MA requirements and recommendations for harvested vegetables. Proceedings of Seventh Intermational Controlled Atmosphere Conference, Vol. 4. Postharvest Outreach Program, University of Califormia, Davis, CA: 98-117

Yano, M., Saiji, R. and Y. Ota 1986 Inhibition of browning and ethylene production in shredded cabbage by isothiocyanates. J. Japan. Soc. Hort. Sci., 55: 194-198 (In Japanese)

Watada, A. E., N. P. Ko and D. A. Minott 1996 Factors affecting of fresh-cut horticultural products. Postharvest Bio. Technol., 9: 115-125

Watada, A. E. and L. Qi 1999 Quality of fresh-cut produce. Postharvest Bio. Technol., 15: 201-205

Zagory, D and A. A, Kader 1988 Modified atmosphere packaging of fresh produce. Food Technol., 42: $70-77$ 